\title{
Urban sprawl and its effects on water demand: A case study of Alicante, Spain
}

\author{
3 Q1 Alvaro Francisco Morote Seguido*, María Hernández \\ 4 Q2 Interuniversity Institute of Geography, University of Alicante, Carretera de Sant Vicent del Raspeig, s/n 03690 Sant Vicent del Raspeig, Alacant, Spain
}

Article history:

Received 17 November 2014

Received in revised form 18 May 2015

Accepted 15 June 2015

Keywords:

Urban land area

Types of urban development

Changes

Land uses

Water

Alicante coastline (Spain)

\begin{abstract}
A B S T R A C T
Since the mid-1990s, there has been a significant increase in the urban-residential land area of the provincial coastline of Alicante, Spain. This residential growth has mostly affected municipalities that first saw the arrival of tourism in the 1960s and 1970s but also affects new territories, primarily those slightly set back from the coastline. The aim of this paper is to highlight the consequences of changes in the urbanised land area over time and space on land resources and, indirectly, the relation between new urban typologies and water demand. To this end, this process will be analysed with a focus on such factors as the intensity of the process, the type of urban development and spatial differences in the rate of construction. The methodology used studies the urbanised land area by means of photogrammetric restitution of land uses in 1956, 1978 and 2013 and the development of cartography according to the dominant types of urban development. This data source will be complemented with statistical information pertaining to housing and water consumption.
\end{abstract}

(C) 2015 Published by Elsevier Ltd.

\section{Introduction}

Since the late 1990s and particularly at the start of the 21st century, considerable research has highlighted the consequences of multiple urban developments in different regions following patterns of low residential density in Europe (EEA, 2006). This urban-residential expansion has often been located along coastal areas, for example in Ireland, Portugal and above all in the Spanish Mediterranean (Gaja, 2008), where a report drafted by the European Environment Agency (2009) forecast that between 1995 and 2025 the urbanised land area would increase from 55\% to 73\% of total land area. On the European Mediterranean coastline, the increase in urbanisation fundamentally pertains to the building of homes, either main or second homes, for the Spanish and European population (Hernández, 2013).

Spain, and more specifically the Mediterranean coastal provinces, including Alicante, has sustained a substantial increase in urbanised land areas as a consequence of the spread of residential tourism uses since the 1960s. These dynamics are related to the development of tourist activities that have been favoured by

\footnotetext{
* Corresponding author. Present address: Interuniversity Institute of Geography

(University of Alicante, Spain), Carretera de Sant Vicent del Raspeig, s/n 03690 Sant Vicent del Raspeig, Alacant, Spain.

E-mail addresses: alvaro.morote@ua.es (A.F.M. Seguido). maria.hernandez@ua.es (M. Hernández).
}

the temperate climate, the sea, and the area's proximity to origins of outbound tourism in Europe (Vera, 1987). Furthermore, there are internal factors related to Spain's liberalising attitude of the 1970s, which incorporated the tourist sector into its economic policy actions with a view to obtain maximum growth for the country (Navalón, 1999). In addition to these causes, the process of economic liberalisation and diversification promoted by the government perceived tourism as a fundamental factor along with the real estate bubble linked to tourism (Pack, 2006), which was based on an initial construction of hotels and, subsequently, of residential accommodation for tourism purposes (Baños, 1999; Rico et al., 2009). This process has characterised large sections of the Spanish Mediterranean coastline, including the Balearic Islands, which has a long tradition of this process (Salvà, 2002), the Costa del Sol (Raya and Benítez, 2002) and the coastline of Murcia (Monreal, 2001), along with the European Mediterranean coastline (the French Cote D'Azur) and Florida (Fernández and Barrado, 2011).

Since the 1960s, coastal and pre-coastal municipalities of Alicante have undergone substantial land use transformations that are largely part of the dynamics of change which have characterised the entire Spanish Mediterranean coastline (Del Romero, 2008). The majority of coastal and pre-coastal municipalities in the province of Alicante have modernised their productive functions on the back of "residential tourism"(Vera, 2005; Mantecón, 2012). This concept has been used since the late 1970s to explain the social, economic, and land use changes generated by the increase in two forms 
of human mobility: tourism and migration (Huete and Mantecón, 2010). This is, therefore, an activity that is associated, on the one hand, with traditional ways of spending summers, and on the other, with new lifestyles and types of residential mobility linked to the mass construction of second homes (Huete et al., 2008). The latter focuses on the arrival of so-called climate residents; in other words, large sections of the foreign population from central and northern Europe who choose to come here because of the mild climate (King et al., 2000; Casado-Diaz, 2006; Casado-Diaz et al., 2014). These people buy a house for summer living or as a yearround home for climate or health reasons (Huete, 2009). They have settled mostly in urban spaces created specifically for them, with urban types similar to those of their origin area instead of traditional urban centres. This collective (the population from central and northern Europe) is the population group that predominates in the coastal and pre-coastal municipalities of Alicante (Huete and Mantecón, 2010; Membrado, 2015). There is a second group which is an immigrant population. These people are from South America, Eastern Europe and North Africa (Piqueras, 2012). They arrived in this area to work. This population, unlike the previous, sits in the traditional urban centres and, generally, in peripheral or marginal neighbourhoods (Gil et al., 2015).

The expansion of the residential and tourist population, incentivised for decades by different administrations, has brought about strong competition for land and water use with other economic (agriculture) and environmental functions (wetlands) (March et al., 2014). One object of study that has been linked with this residential expansion and is not without controversy pertains to the relationships established between water demands and available resources (Troy and Holoway, 2004) and the changes this has generated from the perspective of land use and the transformation of the landscape (Albert and Rullán, 2007; Hof and Blázquez-Salom, 2013).

The remainder of this paper is structured as follows. Following a brief outline of the objectives and working methods implemented in this study, evidence will be provided of the expansion of urban-residential uses and the factors that have made this possible. Subsequently, reference will be made to the land use and social consequences associated with this process, paying particular attention to the effects on water consumption.

\section{Study area, objectives and methods}

The hypothesis examined in this paper entails ascertaining the relationships established between the expansion of residential tourism uses and the increased consumption of water resources. This assumption, which appears to be evident, raises certain questions regarding the evolution of water demands over the past decade in numerous cities in developed areas. The studies carried out in various countries in northern and central Europe (Schleich and Hillenbrand, 2007; Environment Agency, 2008), in the United States (Cohen et al., 2004) and in Spain, in the Metropolitan Area of Barcelona (Domene and Saurí, 2006) and Madrid (Cubillo et al., 2008), highlight the decline in domestic consumption since the mid-1990s.

To gain a better understanding of the relationships established between urban expansion and water consumption, we must first examine the factors that affect this demand, paying particular attention to changes in land usage. On the basis of the starting hypothesis, this research pursues the following aims:

- Highlight changes in the urbanised land area, paying particular attention to factors that explain the spread of these uses

- Provide evidence of the introduction of these uses over time, and taking account of the land area occupied by different types of urban typologies. This distinction is fundamental, given the dif- ferent consumption associated with each type and, specifically, the greater or lesser presence of outdoor uses in homes

- Show the main land use repercussions associated with this process, focusing particularly on water consumption and the relation between new urban typologies and water demand.

Therefore, the objective of this article is to highlight the urban sprawl process in the coastal municipalities of Alicante province between 1956 and 2013, the causes that explain this process and the impact on water demand. In this sense, the study area chosen is relevant because the increase of urban sprawl in the Mediterranean Spanish coast. The province of Alicante is located in southeast Mediterranean Spain (see Fig. 1) and until the 1990s enjoyed a relatively diversified productive base including irrigated agriculture, the manufacturing of consumer goods, and tourism in the coast with emblematic centres of mass tourism such as Benidorm (Rico et al., 2009). Since the late 1990s, however, a real estate bubble fuelled, as in most of the world, by cheap credit, absorbed larger and larger parts of the economic activity. Thus, between 1997 and 2008, Alicante ranked third in Spain in housing units built $(345,410)$, after Madrid and Barcelona and ahead of provinces with larger populations such as Valencia or Málaga (Hernández et al., 2014).

To achieve this, the following are discussed: (a) the implementation process for residential uses (considering the factor of time). Three time horizons were chosen to represent changes on the coastline of Alicante province, specifically 1956, 1978 and 2013. The reasons justifying the choice of these years were determined by technical factors (availability of aerial photography or satellite images) and by socioeconomic dynamics. In 1956, the main economic basis of all coastal and pre-coastal municipalities was agriculture and fishing, whereas urban-residential land linked with tourist activity was practically non-existent. In 1978, the presence of tourist activity on the coastline was significant because the implementation of these activities began in the 1960s. This time horizon corresponds to a first phase of residential use expansion, which took place during the 1960s and the beginning of the 1970s. The last date (2013) corresponds to the current situation, in which urban-residential dynamics are the predominant use in coastal and pre-coastal areas and after a second great period of urban growth; (b) Changes in urban typologies, with particular attention to those with outdoor uses (gardens and swimming pools); and (c) the analysis of both elements, which is intended to highlight the causes of urban sprawl and its effects on water demand.

The analysed municipalities (a total of 33) are located on the coastline and pre-coastline of Alicante province (Spain), where tourist activity has influenced the real estate development of the urban land area (Fig. 1). When analysing the studied municipalities, the cities of Alicante and Elche were excluded because the first is the province capital, a services-based city with a sizeable urban area, and Elche is an industrial city. Furthermore, in both cases, the growth of the urban-residential area is not linked to tourist activity, although they both have tourist uses concentrated on the seafront. In the study of land use dynamics, a distinction is drawn between the northern coastline (19 municipalities) and the southern coastline ( 14 municipalities), given the differences evidenced by the implementation of residential uses in the territory.

The working method is based on analysing aerial photographs and satellite images, along with statistical sources pertaining mostly to population and housing changes. The photographs and images used, based on photogrammetric restitution, have enabled changes in land areas to be calculated both in general and according to different uses. The statistical sources used have confirmed changes in land uses and also reflect the consequent social and land use impacts.

Having selected the points in time to be used, the urbanresidential land area of the coastline of Alicante province was 


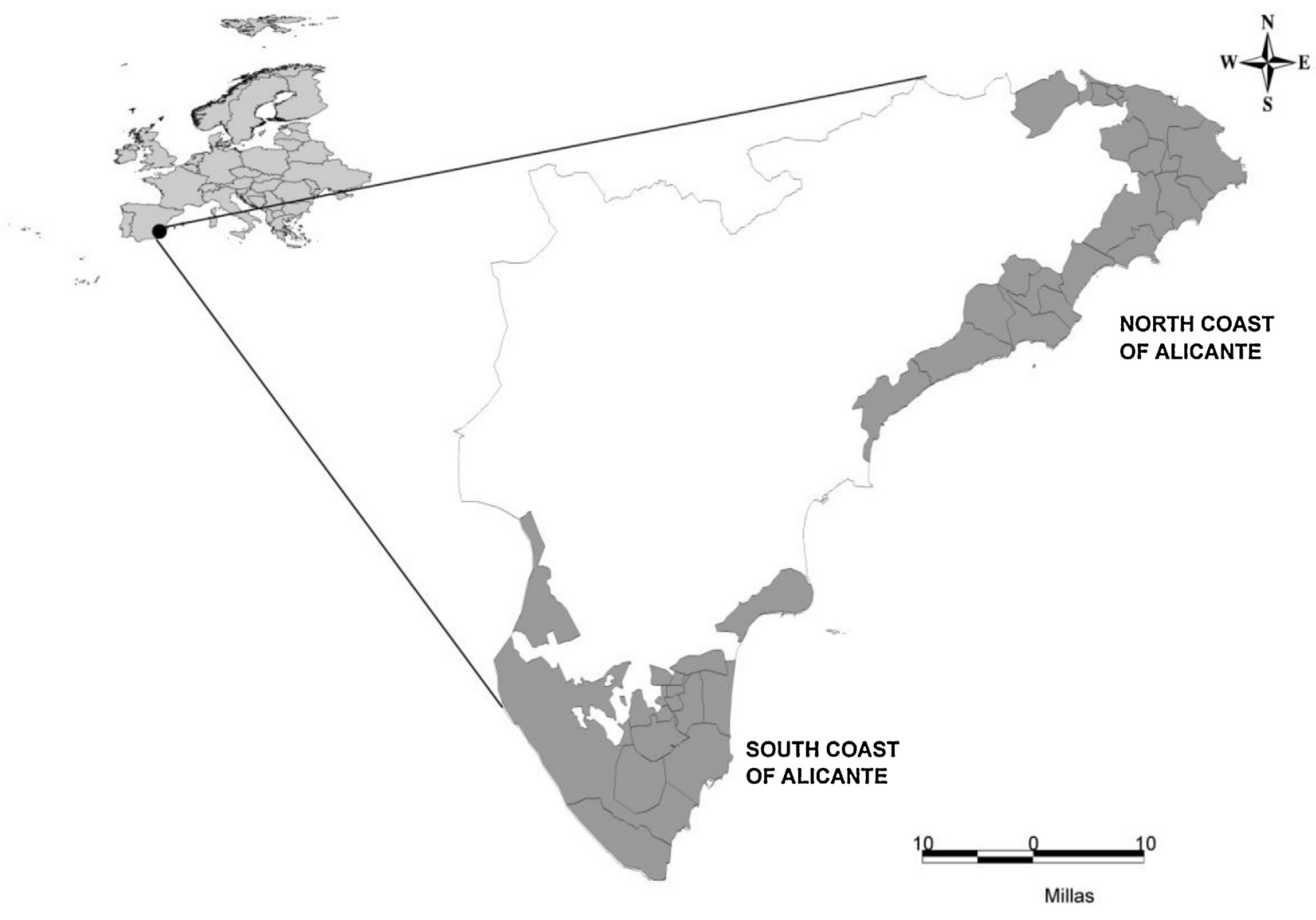

Source: authors.

Fig. 1. Study area.

digitised. For the year 1956, American aerial photographs were used; for 1978 the aerial photographs of the Air Force, and for the year 2013 the orthophotographs of the National Aerial Orthography Plan (PNOA).

Given the aims of this paper, when analysing land uses, spaces dominated by agricultural uses were excluded. In parallel, in areas where urban uses were predominant, a distinction was drawn between various types of residential uses depending on the morphology observed:

- Urban core. This label was applied to traditional population nuclei, such as hamlets and fishing villages. This corresponds to compact morphology.

- Apartments with a garden and/or swimming pool. These correspond to high-rise blocks of homes with community areas (garden and/or swimming pool) for their residents.

- Semi-detached houses. These are houses with 1 or 2 floors integrated into residential complexes, where the defining characteristic is that they are juxtaposed with other dwellings. They are also characterised by having a garden and community swimming pool.

- Detached houses. These are houses ( 1 or 2 floors) with private garden and/or swimming pool. They can be isolated or integrated into low-density developments.

- Non-residential urban land. This category covers uses that are integrated into the urban land area, corresponding to shopping and leisure centres, sports centres, hospitals, industrial estates, etc.
Having digitalised the different types of urban-residential development, the land area was calculated in $\mathrm{m}^{2}$ at a general level and also by type of urban development. The data obtained highlight changes in land uses over the three time horizons selected from a general perspective and also by type. By consulting various databases, such as the population and housing census for the time horizons studied, as well as specific data, such as changes in housing approved by the College of Architects or consumption of water supplied by companies that manage the declining consumption of this resource, conclusions can be reached about the repercussions of this process. These data have been provided by the company which supplied water in the major part of municipalities of the coast of Alicante (Hidraqua, Gestión Integral de Aguas de Levante S.A.).

\section{Results}

The use of the GIS methodology shows the changes in land uses highlights and the functionality registered by coastal and precoastal municipalities in Alicante. These transformations can be summarised, roughly, as the transformation from an eminently farming-based society to one that is service-driven. In this part of the paper we explain land use changes, the causes of this process and the impacts on water resources.

\subsection{Real estate bubble: the case of Alicante}

In 1956, the main economic activities on the coastline of Alicante province were farming, fishing, and, in some municipalities, industry. Tourist activity was not yet significant, with the excep- 
Table 1

Changes in land uses $\left(\mathrm{m}^{2}\right)$ by type of urban-residential development on the coastline of Alicante province (1956-2013).

\begin{tabular}{|c|c|c|c|c|c|c|}
\hline & \multicolumn{2}{|l|}{1956} & \multicolumn{2}{|l|}{1978} & \multicolumn{2}{|l|}{2013} \\
\hline & $\mathrm{m}^{2}$ & $\%$ & $\mathrm{~m}^{2}$ & $\%$ & $\mathrm{~m}^{2}$ & $\%$ \\
\hline Urban core & $7,788,274$ & 91.8 & $14,383,623$ & 28.8 & $25,285,463$ & 11.4 \\
\hline Detached houses & 693,236 & 8.2 & $29,128,214$ & 58.3 & $127,536,590$ & 57.5 \\
\hline Apartments with garden and pool & Neg.* & Neg.* & $2,963,644$ & 5.9 & $11,329,937$ & 5.1 \\
\hline Semi-detached houses & Neg.* & Neg.* & 919,436 & 1.8 & $29,875,727$ & 13.4 \\
\hline Non residential use & Neg.* & Neg.* & $2,509,234$ & 5.1 & $27,938,019$ & 12.6 \\
\hline Total & $8,481,510$ & 100.0 & $49,904,151$ & 100.0 & $221,965,736$ & 100.0 \\
\hline
\end{tabular}

Excluding the municipalities of Elche and Alicante. Neg.* (negligible).

Source: photogrammic restitution from flights in 1956 and 1978 and satellite imagery from 2013.

Restitution conducted by the authors.

tion of some localities where tourism was traditionally linked with spa resorts and with the holiday homes of the bourgeoisie (Vera, 1987), but its repercussion from the perspective of land usage was minimal. The predominance of an eminently farming-based society is reflected in the types of urban development that existed. There was an overwhelming predominance of traditional urban nuclei, which corresponded to approximately $92 \%$ of urban uses (Table 1). The remaining percentage pertained to "low-density urbanisation" associated with second homes belonging to the wealthier classes (Morote, 2014).

Land uses in 1978 reflect the implementation of residential tourism activities that affected the coastal municipalities of Alicante during the 1960s and early 1970s. This dynamic is reflected in the increase in urban land area between 1956 and 1978, which multiplied almost six-fold (Table 1). If the increase in urban usage is evident, the changes registered by the different types of urban development are even more transcendent. Low-density developments experienced the highest increase in land area (both in absolute and relative terms) from approximately $700,000 \mathrm{~m}^{2}$ to over 29 million. In the spread of residential tourism, two new types of urban development can be observed: semi-detached houses and apartments with a garden and swimming pool. From the perspective of land use, their repercussion is minimal because they affect less than $7 \%$ of urban uses. These types are associated with houses used for tourism purposes, but with significant differences regarding the provenance of their owners. The foreign population generally tends to buy low-density houses, imitating the urbanisation characteristics of their homeland (central and northern Europe) as opposed to the Spanish population, which tends to buy more compact houses (semi-detached houses and apartments), but with gardens and swimming pools, given their recreational use (Torres, 1997; Morote and Hernández, 2014).

The process of reform resulting from urban-residential uses developed continually during the 1980 s and 1990s. After the mid-1990s, these territories registered a very intense process of urbanisation. This dynamic coincides with the spectacular real estate bubble that affected the whole of the Spanish Mediterranean coastline and which came to an end in 2008 when the housing bubble burst (Burriel, 2008). This process is not unique because there are also examples of real estate bubbles in countries such as Ireland, the United States and Japan (Torrero, 2001). In 2013, the dominance of urban-residential uses in coastal and pre-coastal municipalities on the Alicante coastline was very high; only residual sectors have been excluded, generally under some type of protection regulation. A few figures highlight the intensity of the urbanisation process on the Spanish Mediterranean coastline, and in particular on the coastline of Alicante province. The 11 Spanish Mediterranean coastal provinces account for 2,487,262 new houses authorised for the period 2000-2011, representing $43.88 \%$ of the national total. This activity is surprising in the province of Alicante, placing it third in the national ranking $(345,410)$ after Madrid and Barcelona, and above provinces with higher population fig- ures (de jure population) such as Valencia or Málaga, right on the Spanish Mediterranean shore (Hernández et al., 2010). From the perspective of the urban land area, the total urbanised area stands at $221,965,736 \mathrm{~m}^{2}$, which is over four times more than in 1978 .

The comparison of the figures for secondary housing between 1991 and 2011 highlight the importance of this real estate bubble. The percentage of second homes in 2001 stood at approximately $22 \%$ of the total number of houses, and this figure would increase to $40 \%$ when taking into account empty houses, as opposed to $15 \%$ in 1991 and as low as 3\% in 1960; the percentage remained steady between 2001 and 2011. These figures increase significantly when we look at the local scale: in practically all of Alicante's coastal and pre-coastal municipalities, over $50 \%$ of all homes are not primary places of residence, a value that is much higher than the average for the province as a whole, which stands at 26.9\% (INE, 2012).

The process of urban sprawl on the coast of Alicante presents a series of features that resemble other areas dominated by residential tourism, such as the Balearic Islands or the coast of Málaga, and expansion of the metropolitan belts of large cities such as Barcelona, Madrid or Valencia. In this case, the urbanisation process is due to the economic dynamics of the city itself and the preference of its inhabitants for urban typologies less dense than those predominant in urban cores or more affordable housing (March and Saurí, 2010). In this sense, population (a very high prevalence of foreigners from central and northern Europe) and the urban model (new urban spaces that are created apart from the traditional urban cores and occupied almost in their entirety by the foreign population) are the main features characterizing this urban sprawl. Another element to be highlighted is the change in the urban typologies between the different phases of urban sprawl. In general, the main differences between the urban sprawl of the 1960s and 1990s are related to the intensity, to the development of new urban areas and to new urban typologies (questions that will be analysed in successive paragraphs). The housing bubble has been significantly more intense in the 1990s than it was in the 1960s. The development of new urban areas (for residential tourism) in the 1990s is determined by the involvement of pre-coastal municipalities. In the 1960 s, residential uses were concentrated in the coastal municipalities (Fig. 2).

\subsection{Urban sprawl on the North and South coasts of Alicante}

Changes in land uses, in addition to a modification in their functionality and the appearance and subsequent consolidation of new types of urban development, also reflect the existence of different periods of change resulting from residential tourism uses. There are significant differences between the North and South coasts of the province (Fig. 3) in terms of the start of such activities, their intensity, and the predominance of features that define the different types of urban development. The quality of the landscape, the value of the land (understood in terms of productive profitability) 


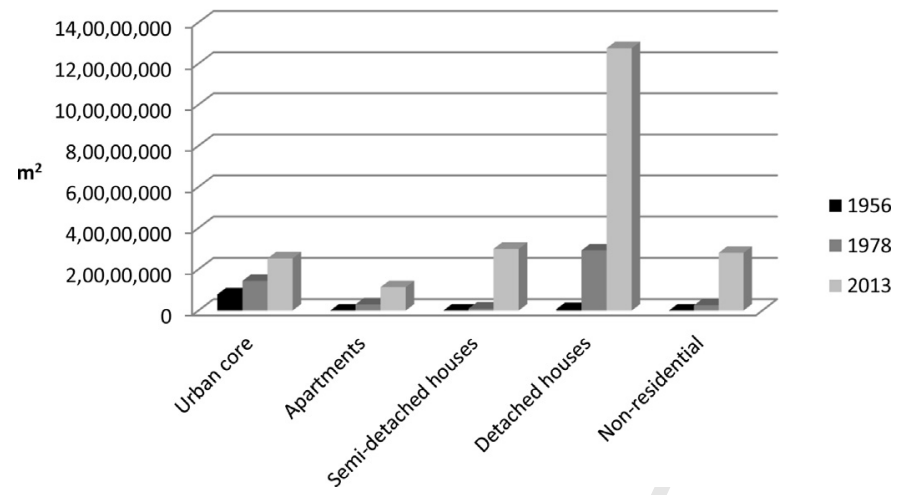

Fig. 2. Evolution of the urban-residential uses on the coast of Alicante (1956-2013).

\section{NORTH COAST OF ALICANTE}

1956

1978
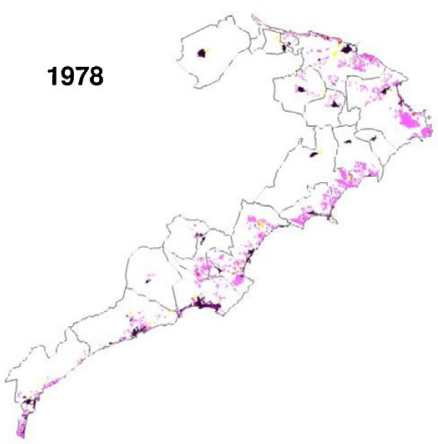

2013
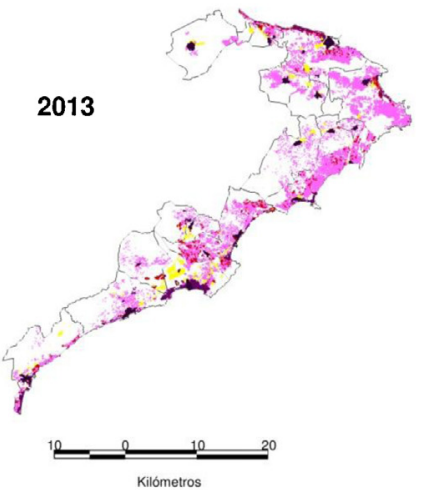

SOUTH COAST OF ALICANTE

1978

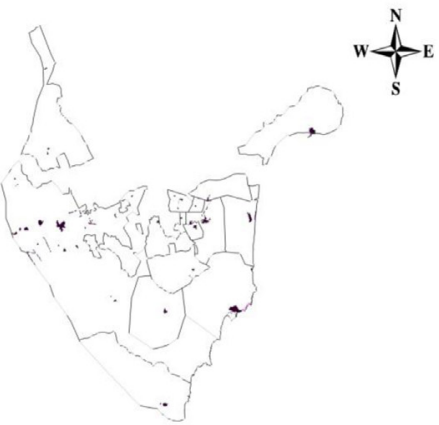

2013
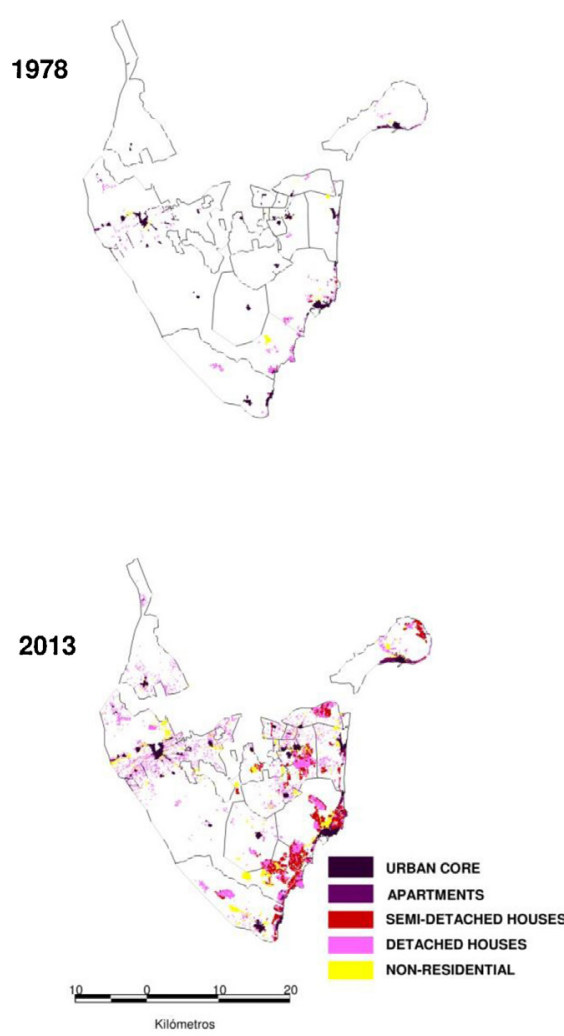

Excluding the municipalities of Elche and Alicante.

Source: photogrammic restitution from flights in 1956 and 1978 and satellite imagery from 2013.

Restitution conducted by the authors.

Fig. 3. Evolution of the residential-urban area on the North and South coasts of Alicante (1956-2013).

Please cite this article in press as: Seguido, A.F.M., Hernández, M., Urban sprawl and its effects on water demand: A case study of Alicante, Spain. Land Use Policy (2015), http://dx.doi.org/10.1016/j.landusepol.2015.06.032 
Table 2

Evolution of the land uses $\left(\mathrm{m}^{2}\right)$ according to urban-residential typologies and coastlines of Alicante (1978-2013).

\begin{tabular}{|c|c|c|c|c|c|c|c|c|}
\hline & \multicolumn{4}{|l|}{1978} & \multicolumn{4}{|l|}{2013} \\
\hline & \multicolumn{2}{|l|}{ North coast } & \multicolumn{2}{|l|}{ South coast } & \multicolumn{2}{|l|}{ North coast } & \multicolumn{2}{|l|}{ South coast } \\
\hline & $\mathrm{m}^{2}$ & $\%$ & $\mathrm{~m}^{2}$ & $\%$ & $\mathrm{~m}^{2}$ & $\%$ & $\mathrm{~m}^{2}$ & $\%$ \\
\hline Urban core & $6,644,122$ & 18.2 & $7,739,501$ & 57.5 & $11,604,015$ & 8.3 & $13,681,448$ & 16.6 \\
\hline Detached houses & $25,479,214$ & 69.9 & $3,649,000$ & 27.1 & $96,371,895$ & 69.2 & $31,164,695$ & 37.1 \\
\hline Apartments with garden and pool & $2,401,005$ & 6.6 & 562,639 & 4.2 & $8,575,289$ & 6.1 & $2,754,648$ & 3.3 \\
\hline Semi-detached houses & 547,814 & 1.5 & 371,622 & 2.8 & $9,304,066$ & 6.7 & $20,571,661$ & 24.9 \\
\hline Non resident & $1,364,985$ & 3.7 & $1,144,249$ & 8.5 & $13,469,742$ & 9.7 & $14,468,277$ & 17.5 \\
\hline Total & $36,437,140$ & 100.0 & $13,467,011$ & 100.0 & $139,325,007$ & 100.0 & $82,640,729$ & 100.0 \\
\hline
\end{tabular}

Excluding the municipalities of Elche and Alicante.

Source: photogrammic restitution from flights in 1956 and 1978 and satellite imagery from 2013.

Restitution conducted by the authors.

and the existence of transport links were all factors that determined where such new uses would first take hold in the 1960s.

The greatest increase in the urban-residential land area came between the mid-1990s and 2008. In 2013, the urbanised land area stood at 222 million square metres, $62 \%$ of which was concentrated on the northern coastline (Table 2). The increase in absolute terms is highly significant. However, the differences between the two stretches of coastline are even more significant. The southern coastline has seen its percentage value increase by 10 points with regard to the total urbanised area. These changes also affect the distribution of different types of urban development. Semi-detached houses, low-density urbanisation and non-residential urban land all surpass the percentage of land occupied by the traditional urban nucleus (16.6\%). Just as on the northern coastline in the 1970 s, here the urban-residential model has been synthesised in the proliferation of new urbanised spaces constructed outside the traditional villages.

The spread of these activities in subsequent periods was determined by a dual process: on the one hand, the congestion of certain territories and its spread towards spaces with cheaper land uses and a greater quality of landscape, generally further inland; and on the other, changes in these uses in coastal sectors with a scarce or almost non-existent presence of such activities previously. The first of the dynamics described above took place first, once again, on the northern coastline. Hence, in the late 1970s, residential tourism uses had mostly been implemented on the coast, and they were beginning to spread towards pre-coastal municipalities (between 5 and $10 \mathrm{~km}$ from the coast), giving rise to a 'second coastline.' At the start of the 1990s, the coastline and 'second coastline' were characterised by high levels of occupancy in terms of land uses, and this process, coinciding with the real estate bubble registered between 1998 and 2007, spread towards a third belt further inland, towards municipalities that could be as far as $20 \mathrm{~km}$ from the coast (Fig. 3). On the southern coastline, real estate development related to tourist activity has been more recent, with the exception of a few very specific areas. This late implementation is tied to two processes. First are the higher levels of farming profitability, which are associated with the transformation of dry lands into irrigated lands and the spread of fruit and vegetable crop farming. Second is the inferior quality of the landscape, owing to the predominance of flatter spaces coinciding largely with the final section of the River Segura's course and the predominance of more ochre hues because of lower rainfall levels. The reduction in farming profitability, due to the economic crisis affecting some of the majority crops, has facilitated this reconversion over to residential and recreational uses (golf courses). However, this implementation has been characterised by extremely high levels of housing construction since the 1990s, which boosted these municipalities up to the top of the ranking for authorised housing at a national level in the 1990s. Urban-residential uses have affected the immediate coastline, but they have also affected sectors of the 'second coastline,' which had previously been dominated by farming uses.

The differences between the two stretches of coastline are not limited solely to the period in which residential-tourism uses were initiated and spread; they also extend to the predominant types of urban development (Table 2). In the North, low-density urbanisation has prevailed over other types of urban development since the urbanisation process began in the 1960s. In spite of the substantial growth registered in absolute terms, the percentage variation is minimal. In the South, on the other hand, there is no clear predominance of one type over the others. Another specific feature of this sector is the fact that in the process of urbanisation, types of urban development with very little previous importance, such as semi-detached houses, have registered a substantial increase in terms of the land area occupied, in absolute terms and as a percentage, from barely $2.8 \%$ in 1978 to almost $25 \%$ of the urbanised land area. Another differential factor pertains to the "low-density" type of urban development: although it is slightly predominant over the rest, there are still differences with the northern coastline. On the northern coast, plots of land with detached houses are larger in size (940 $\mathrm{m}^{2}$ on average) and the outdoor spaces, particularly the gardens, are larger (Fig. 4). On the southern coast, on the other hand, although the houses have gardens and single-family pools, they are characterised by a smaller plot size $\left(416 \mathrm{~m}^{2}\right.$ on average), making them more similar to the semi-detached model of urban development (Morote and Hernández, 2014). The lower income level of residents on the southern coast is one of the factors that explain the prevalence of semi-detached houses and smaller plot sizes.

\subsection{Causes behind urban sprawl in the coastal municipalities of Alicante}

The combination of a series of causes (socio-economic, cultural, systems of mobility and urban planning regulations) helps to understand the magnitude of this phenomenon. Some of these factors are stretched out over time and others have a more temporary effect. First, we should mention political factors and, more specifically, the liberalisation policies of Franco's regime in the 1960s, which perceived tourism as an activity that, would enable the modernisation of Spain (Vera, 1987).

Second, it is worth mentioning the arrival of people from the Centre and North of Europe, drawn by the temperate climate and the possibility of buying houses at low cost in comparison to their home residences (Casado-Diaz, 2012a,b). This arrival is reflected in the population census. In the year 2001, the foreign population percentage stood at $4.5 \%$ of the national total, and increased to $12.1 \%$ in 2011 (INE, 2012). In provinces that lie along the Mediterranean coastline, including Alicante, the figure is without exception higher than $15 \%$ of the total population. Specifically, Alicante has increased from $14.7 \%$ in 2001 to over $24 \%$ in 2011 (INE, 2012). This figure 

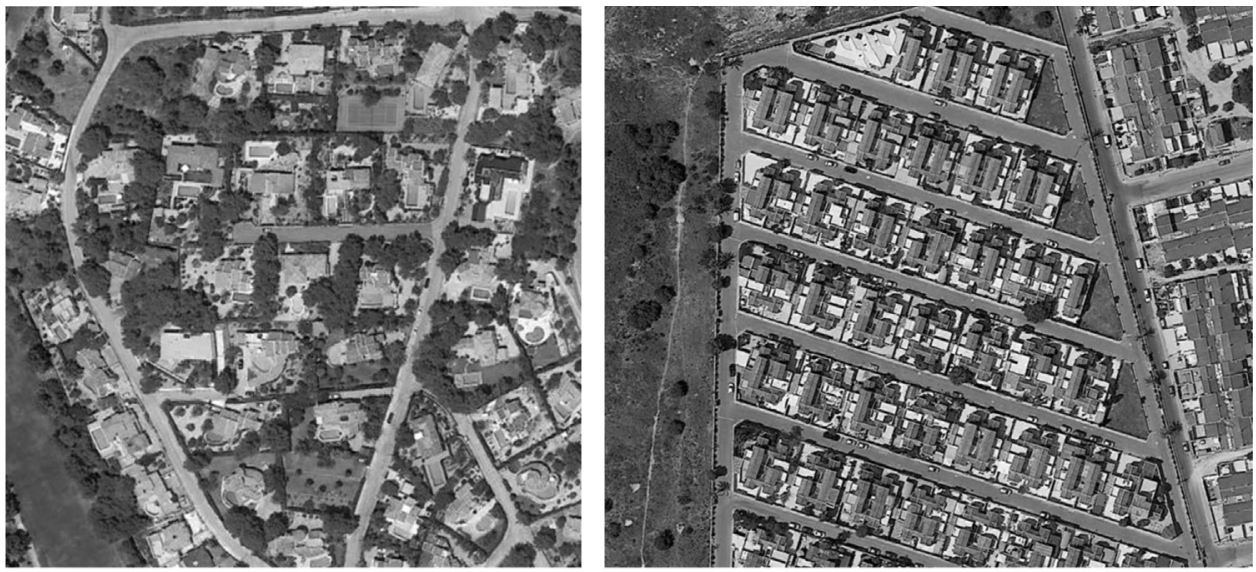

Source: https://www.google.es/maps

Fig. 4. Example of the low-density type of urban development on the northern coastline (left) and southern coastline (right) of Alicante.

takes on an even greater magnitude at a regional and local level. Analysis at a local level reflects the intense arrival of people from northern and central Europe (the so-called climate residents) in the past decade, which is concentrated mainly in the coastal and pre-coastal municipalities of Alicante. Of particular note are municipalities such as Rojales, San Fulgencio and San Miguel de Salinas (all on the southern coastline of the province), in which foreign residents increased from $35 \%$ to $70 \%$ of the total population between 2001 and 2011, respectively, occupying the top positions in the ranking of Spanish municipalities with the highest number of foreigners. These are also the municipalities where climate residents account for more than $90 \%$ of the total non-Spanish population (INE, 2012).

The first wave of immigrants (in the 1960s and 1970s) was facilitated by the improvement of infrastructure, including the opening of Alicante's airport (1967) and the construction of the Ap-7 motorway (1978), which facilitated connections between outbound and inbound tourist areas and the development of residential uses on the municipalities of the northern coast of Alicante. The development of infrastructure and improvement of transport links incentivised by EU Cohesion Funds and Structural Funds have translated into an intensification of the arrival of immigrant populations from northern and central Europe since the 1990s. The reduction in travel time and the reduced costs of travelling between main residence and holiday home, between the Spanish Mediterranean coastline and the rest of Europe, and even from areas further inland in Spain towards the coastline, have facilitated this increase in mobility. These dynamics have expanded towards peri-urban areas and sectors close to the axes of urban development, which is the case, for example, between the coasts of Alicante or Málaga province and their inland mountainous areas, configuring a second and even third "coastline," as happened on the northern coast of Alicante, or the development of intensive processes of residential development, as happened on the southern coast. The popularisation of low-cost flights since the late 1990s has enabled millions of tourists to travel and to go back to places several times a year, a key factor in choosing emblematic tourist areas such as the province of Alicante, the Costa del Sol and the Algarve, and in general when making a decision to buy a dwelling in Spain (King et al., 2000; Huete, 2009). Alicante's airport received ten million passengers between October 2013 and September 2014 (Aeropuerto de Alicante-Elche, 2014), with a total of 71,233 flights, making it the sixth-busiest airport in Spain in terms of passenger movement, behind Madrid, Barcelona, Palma de Mallorca, Málaga and Gran Canaria, and one of the 50 most-used airports in Europe. Approxi- mately $75 \%$ of passengers comprising Alicante's airport traffic take international flights from the UK, Germany and Holland.

A third factor is the implementation of local and regional urban organisation policies and, more specifically, regulations that impact land usage and urban planning. In this respect, mention should be made of the liberalisation of the urbanisation process following the introduction of an Act Regulating Urban Activity in the Region of Valencia (1994), which streamlined procedures for the development of urban projects (Burriel, 2009). Also of significance is the consideration of "Green Belt Land," which, according to land use planning, "should be designated for uses pertaining to the rustic nature of the lands " (Art. 1, Act 10/2004, dated 9 December, passed by the Valencian Regional Government, regarding Green Belt Land). In spite of the limitations in place, it is precisely on this type of land where extensive urbanisation has propagated at a very fast pace in many municipalities. The income-generating policies pursued by local councils through building permits and planning reviews, with a view to creating land suitable for building, became very widespread practices (Hernández et al., 2008). These legislative modifications and the economic income they generated for the local budget translated into regional governments adopting a very favourable stance towards unlimited urban growth, in which the speculative nature of urban proposals was another characteristic of the real estate bubble (Romero et al., 2012).

Last but by no means least, we have the purchase of real estate as a safe investment. This factor is associated with falling interest rates and the improvements made by mortgage providers to lending conditions against a background of high rates of family savings and the increase in disposable cash allocated to house investment resulting from stock market divestitures and tax reforms in Spain. This factor is also associated with increased international demand for dwellings in Spain's tourist areas, fostered by very favourable economic conditions. Investments in real estate as a safe bet are also associated with the purchase of property as a means of laundering money (Naredo and Montiel, 2011).

\subsection{Urban sprawl and water demand}

During recent decades, and particularly in the southern areas of Alicante, industrial, recreational and residential uses have come to occupy a large part of once-irrigated croplands. Hence, it has become common to execute urban plans to construct large urban developments on small topographical reliefs with good views of the landscape. In fact, in some municipalities, more than $50 \%$ of irrigated cropland has been lost as a result during the 1985-2000 period (Rico and Hernández, 2008). 
Numerous publications make reference to the fact that the increase in the urban-residential land area has been based on extensive urbanisation, with the introduction of new urban natures such as gardens and swimming pools (Swyngedouw, 2004; Leichenko and Solecki, 2005; Larsen and Harlan, 2006; Fernández et al., 2011; Parés et al., 2013; Morote and Hernández, 2014). The research into these processes also highlights that low-density residential expansion tends to have a greater environmental impact than higher-density urban development (Breheny, 1992; Domene et al., 2004).

Studies carried out in the coastal municipalities of Alicante in 2013 and 2014 show, on the one hand, a change in trends for consumption demand, and on the other, a differentiation in the volumes consumed between municipalities on the North and South coastlines. In general, the trend of water consumption has been increased since 1960s until 2004-2005 in all municipalities due to the raise of houses and population and related with tourist activity (see Rico, 2007). After that, a reduction of approximately $20 \%$ in domestic consumption has been registered in most villages (Gil et al., 2015). In this respect, there is extensive empirical evidence showing the decline in water consumption in recent decades in most of the large urban agglomerations of developed countries (Saurí, 2003). In Germany, for example, the consumption between 1994 and 2004 fell by $13 \%$, placing average consumption per inhabitant per day at 1261 (Schleich and Hillenbrand, 2007). Higher values can be observed in Denmark, where the decline between 1989 and 2008 reached 22\% (Environment Agency, 2008). In Spain, the consumption of water per inhabitant per day fell from 1751 in 2004 to 142 in 2011 (INE, 2014). In the city of Alicante, consumption per inhabitant per day stood at $119 \mathrm{l}$ in 2013, in contrast to $200 \mathrm{l}$ in 1991 (Gil et al., 2015).

We can also observe this tendency in our study area when taking into account the data provided by water companies such as Hidraqua. Consumption, for example, in municipalities such as Torrevieja (southern coast) went from $8 \mathrm{hm}^{3}$ in 2000 , to 9.2 in 2005, when it reached its highest levels, then fell to $7.7 \mathrm{hm}^{3}$ by 2013 . Benidorm (northern coast), where hotels provide most tourist accommodations, decreased its consumption between 2005 and 2013 by almost $2 \mathrm{hm}^{3}$, to $9.4 \mathrm{hm}^{3}$ in 2013 . On the northern coastline, in La Nucía, consumption oscillated between $1.7 \mathrm{hm}^{3}$ in 2000, 2.1 in 2005 and 1.4 in 2013. The fall in domestic water consumption, despite the substantial increase in the number of dwellings, corresponds to structural and situational factors, not to mention that a high percentage (approximately 35\%) of the new dwelling units is secondary or empty units. Structural aspects include the improved efficiency of the distribution network, greater environmental awareness among citizens (responsible consumption), technical improvements in terms of equipment and domestic appliances, and the increase in domestic tariffs. Situational factors include the economic crisis that has been affecting the Spanish economy since 2008 and the decrease in the population (demographic projections). These factors should be joined to inform a series of actions targeted to contain the water consumption. It is necessary to encourage changes in the behaviour of people who have gardens and pools. For example, they may have reduced the green areas in the garden or changed the lawn to succulent plants or paved areas. In the case of the pools, currently, generally, pools are not filled year-round. It is also important to explain the increase in grey water for watering gardens and the use of tanks (see for example Morote and Hernández, 2014).

Another aspect to study is the relation between urban typologies and water demand. In regard to tackling relationships between urbanisation and water consumption, one key aspect to bear in mind is that there is not just one but rather many processes of urbanisation and that each of them entails a different type of demand and behaviour in relation to this resource (Saurí, 2003;
Askew and McGuirk, 2004; Rico, 2007; March et al., 2014). The domestic uses of water tend to evolve in terms of quantity and heterogeneity, depending on the level of socioeconomic development. The range of these uses can be extraordinarily broad, with provisions of a few litres per person per day. For example, in the poorest areas of large cities in the developing world, drinking water is often bought at exorbitant prices, up to provisions of 10001 (or even more) per person per day in some cities with extensive urbanism, large lawns and swimming pools located in arid parts of the United States and Australia (Loh and Coghlan, 2003; Askew and McGuirk, 2004; Leichenko and Solecki, 2005).

The characteristics that define urban models can be decisive in terms of gaining a better understanding of water demand. Resource consumptions are different based on the existing urban typologies (Domene and Saurí, 2006; García, 2012). Hence, the consumption of water in high-density urban areas is clearly lower than in lowdensity urban areas (in relative terms per inhabitant) since in these latter areas there is a strong presence of outdoor areas such as gardens and swimming pools (Vidal et al., 2011). Garden areas have become one of the outdoor home elements that consume the highest amount of water resources (Domene and Saurí, 2003, 2006) as a consequence of the installation of lawns (Parés et al., 2004, 2013; Férnandez et al., 2011; Salvador et al., 2011) or the introduction of deciduous plants, which generate new urban natures (Swyngedouw, 1999). The study of the factors (social, economic, cultural, etc.), involved in choosing garden areas explains the proliferation of these outdoor spaces, the reasons behind choosing one type of garden or another, the irrigation systems, management and provenance of water resources, etc. These issues have been studied chiefly in Anglo-Saxon contexts, predominantly the United States, United Kingdom and Australia (Renwick and Archibald, 1998; Mayer et al., 1999; Loh and Coghlan, 2003; Hurd, 2006).

In the case of Spain, such issues have been studied primarily in Catalonia (Domene and Saurí, 2003; Parés et al., 2004; Vidal et al. 2011; García, 2014; Padullés et al., 2014) and in the Balearic Islands (Hof and Schmitt, 2011; Hof and Wolf, 2014), and very recently along the coastline of Alicante (Morote and Hernández, 2014). In our study area, with empirical data from 2013, significant differences between urban typologies have been revealed from the point of view of water consumption on the new urban areas, but these differences were also found within the same urban typology. The type of urban typology will affect water consumption, particularly in homes that have external elements such as gardens and pools. In areas where these new urban natures are detached houses, consumption is higher; however, in residential developments where gardens and swimming pools are in condominium, water usage is shared among neighbours of the residential development, making the use of resources, in this case water, more sustainable. In the detached houses in the North of Alicante, the total water consumption is $5881 /$ house/day. However, on the South coast, water consumption decreases to 3721 . The differences found in terms of water consumption between the northern and southern coasts of Alicante are largely determined by the size of the plot of land and, consequently, by external elements. On the northern coastline, the larger plot size of the gardens of the detached houses $\left(376 \mathrm{~m}^{2}\right)$, in conjunction with the greater presence of gardens, explains how consumption doubles and even triples that of the southern coast $\left(171 \mathrm{~m}^{2}\right.$ ) (Morote and Hernández, 2014). These consumption levels fall significantly in developments of semi-detached houses, where average consumption is approximately 450 litres/inhabitant/day. These values range from 536 to 2841 /house/day between the northern and southern coasts. The smaller size of the garden areas and the greater presence of paved areas are the two factors that explain lower water consumption on the southern coast relative to the northern coast, despite the southern coast's higher solar radiation and lower rainfall. 


\section{Discussion and conclusions}

The coastline of Alicante province has experienced substantial growth in its urban-residential land area since 1956 and, specifically since the mid-1960s, as a result of the spread of residential tourism. Several figures can illustrate this phenomenon. For example, the urbanised land area increased from 8.4 million square metres in 1956 to 49.9 in 1978, and rose to 221.9 in 2013. By then, practically the entire seafront and a high percentage of the 'second coastline' had been urbanised, with this process spreading towards municipalities located between 15 and $20 \mathrm{~km}$ from the actual coast.

The features that summarise the changing functionality of coastal spaces are: (a) the predominance of low-density urbanisations that account for almost $58 \%$ of the total urbanised land area; (b) the configuration of new urbanised spaces outside of the traditional population nucleus; (c) the land use intensity contrast between traditional urban typology (compact, with no external usage) and new urbanised spaces (extensive, with external uses); and (d) the intensity of the process in terms of time and space. Although this dynamic began in the 1960s, it was not until the 1990s that the largest land use transformations were registered on the southern coast. It is on this coastline that the process has been more intense: the increase in urban-residential land area has occurred, with a few exceptions because 1990, in contrast to the northern coastline, where it began in the early 1960s.

Land use transformations associated with the implementation of urban-residential uses have translated into significant repercussions from a land use and social perspective. From a land use point of view, the repercussions include conflicts and increased competition for access to land and water resources, increases in the consumption of certain resources (electricity and water) and the generation of waste (rubbish or black water). These land use changes have also occurred in other parts of the Spanish Mediterranean area, and in Catalonia (Domene et al., 2005; Vidal et al., 2011; Padullés et al., 2014), the Balearic Islands (Salvà, 2002; Albert and Rullán, 2007), Italy (Salvati and Sabbi, 2011), Germany (Schleich and Hillenbrand, 2007), Australia (Loh and Coghlan, 2003; Troy and Holoway, 2004) and Florida (United States of America) (Fernández and Barrado, 2011). The social impacts include urban and social segregation between traditional urban areas and newly urbanised spaces (O'Reilly, 2007). Urban developments are built outside traditional urban nuclei, configuring new residential areas that, generally, are substantially larger in size than the residential urban nucleus. In addition to this physical separation, there is also social segregation. The predominance of foreign residents frequently retired or in early retirement, with limited or no knowledge of Spanish, generates isolation from the local population. This lack of integration is fostered by the fact that often a whole range of services is created by and for this population from central and northern Europe.

This residential expansion has been accompanied by a change in the urban model. From a concentrated urban model, it has moved towards low-density models (detached houses with a swimming pool and garden) and medium-density models (semi-detached houses) and, to a much lesser degree, to high-rise buildings (blocks of apartments). These later two types of urbanisation are integrated into private developments with garden and a swimming pool. The increase in the number of homes and, especially, the adoption of extensive urban typologies given the horizontal nature of their development, requires a high consumption of land and water resources. The diverse evolution of the urban-residential land area between different areas will have repercussions on various aspects of the territory, such as consumption and demand for water because greater or lesser demand will be generated depending on the urbanisation model. In areas dominated by low-density urbanisation (largely made up of detached houses), population density is lower but, in turn, the demand for and consumption of water is proportionally higher because the majority of these dwellings have private pools and gardens. However, in areas dominated by developments of semi-detached houses or apartments, population density is greater, but the consumption and demand for water is lower because swimming pools and gardens are shared with the rest of the residents.

The trend of water consumption has been increased since 1960s until 2004-2005 in all villages due to the raise of houses and population. After that, there has been produced a decreased in water consumption. The general dynamic of domestic water consumption decrease since the end of the nineties could be related to structural and conjunctural factors. This is due to a combination of interrelated causes, the following stand out as being the most significant determinants. Some of the main factors of a structural nature include technical innovations, the efficiency of the supply network, raising the population's awareness, demographic changes and reuse of water. The economic crisis, meanwhile, would be classified as a factor of a temporary nature. We anticipate that the evolution of domestic consumption in the coming years in municipalities in developed countries, which have reached maturity and achieved consolidation in their water consumption patterns, will continue its downward trend, but will be much more moderate than in recent years, as more efficient appliances continue to be installed and changes in consumption habits among citizens become firmly rooted. This will help consolidate lower per capita consumption. Nor do we expect a significant growth in population or a significant increase in the housing market in the short or medium term, which would compensate for the moderation in the per capita consumption.

Water consumption by urban typology provides information about the real expenditure per house rather than the total average expenditure of homes. The characterisation of this type of demand is fundamental to the development of integrated management strategies for water resources and land use organisation in areas with high levels of tourism, leisure and residential activities, even more so when these are joined to problems of drought, pollution and competition with other water uses such as agriculture. This fact warrants special attention because a significant proportion of the dwellings built in the provinces along the Spanish Mediterranean during the real estate bubble are detached residences, many of them used seasonally. These accommodations are chiefly used in the summer and other holiday periods, sometimes leading to restrictions at these times of the year when the demand for water is high (Domene and Saurí, 2006). An example of this is the cistern supply system used in the locality of Javea (northern coast of Alicante) during the summers of the 1980s and 1990s, or the ban on filling up swimming pools and watering gardens using drinking water in the locality of Murla (northern coast of Alicante) during the summer of 2014 as a consequence of the drought.

Perhaps the most important lesson to be learnt from the case of the Alicante coastline is the impact of the different urban residential typologies on water consumption generated by outdoor residential uses. The expansion of the residential and tourist population, incentivised for decades by different administrations, has brought about strong competition with other economic (agriculture) and environmental (wetland) functions for the use of land and water. In low-density developments, i.e., single homes with a single-family garden and swimming pool, water consumption associated with outdoor areas is quite high, mainly due to the exclusive nature of their use by their owners. Urban typology consisting of condominiums and apartment blocks would therefore make for a more responsible and sustainable use of water resources associated with leisure. This is one finding that should be taken into account in the future planning of residential areas. In this sense, it is important to study and analyse the increase of urban sprawl on the coast of 
Alicante due to its impacts on water consumption. For this reason, in this dry region, urban typology is a main element to account for when planning water resources in the future.

\section{Acknowledgements}

The results presented in this article are part of three research studies. The first, entitled "Recent urbanisation processes and sustainable water management: an exploration of relationships in the Mediterranean Coast of the Iberian Peninsula (1991-2008)", was funded by the Spanish Inter-ministerial Commission for Science and Technology (CICYT) as part of its 2009 Funding Programme for Non-oriented Basic Research Projects. The second, "Urbanisation and water metabolism in the coast of Alicante: Analysis of trends for the 2000-2010 period" was funded by the Spanish MINECO under grant number CSO2012-36997-C02-02. The third is part of a PhD research grant funded by the Spanish Ministry of Education. The authors would be thankful for the reviewers' advice and suggestions and the data provides for the company Hidraqua, Gestión Integral de Aguas de Levante S.A.

\section{Appendix A. Supplementary data}

Supplementary data associated with this article can be found, in the online version, at http://dx.doi.org/10.1016/j.landusepol.2015. 06.032 .

\section{References}

Aeropuerto de Alicante-Elche, 2014. http://www.aeropuertos.net/aeropuerto-dealicante/.

Albert, A., Rullán, O., 2007. Nuevo modelo de producción residencial y territorio urbano disperso (Mallorca 1998-2006). In: 9th International Geocriticism Symposium Porto Alegre, 28 May-1 June, http://www.ub.edu/geocrit/9porto/ artigues.htm.

Askew, L.E., McGuirk, P.M., 2004. Watering the suburbs: distinction, conformity and the suburban garden. Aust. Geogr. 35, 17-37.

Baños Castiñeira, C., 1999. Modelos turísticos locales. Análisis comparado de dos destinos de la costa blanca. Investigaciones Geográficas 21, 35-58.

Breheny, M., 1992. The contradictions of the compact city, a review. In: Breheny, M. (Ed.), Sustainable Development and Urban Form. Pion Limited, London, pp. $138-159$.

Burriel, E., 2008. La década prodigiosa del urbanismo español (1997-2006). Scripta Nova. Revista Electrónica de Geografía y Ciencias Sociales, vol. XII, núm. 270 (64). http://www.ub.es/geocrit/sn/sn-270/sn-270/sn-270-64.htm.

Burriel, E., 2009. La planificación territorial en la Comunidad Valenciana (1986-2009). Scripta Nova XIII (306). 1 de diciembre de 2009, http://www.ub. edu/geocrit/sn/sn-306.htm.

Casado-Diaz, M., 2006. Retiring to Spain: an analysis of difference among North European nationals. J. Ethnic Migration Stud. 32 (8), 339, 321-1.339.

Casado-Diaz, M., 2012a. Exploring the geographies of lifestyle mo- bility: current and future fields of enquiry. In: Wilson, J. (Ed.), The Routledge Handbook of Tourism Geographies. Routledge, pp. 120-125.

Casado-Diaz, M., 2012b. The geographies of lifestyle mobilities: Exploring international retirement migration to Spain. In: American Association of Geographers Annual Meeting, New York, USA, 24-29 February 2012. Casado-Diaz, M., Casado-Diaz, A.B., Casado-Diaz, J.M., 2014. Linking tourism, retirement migration and social capital. Tourism Geogr.: An Int. J. Tourism Space. Place Environ. 16 (1), 124-140.

Cohen, R., Wolff, G., Nelson, B., 2004. The Hidden Costs of California's Water Supply. Natural Resources Defense Council \& Pacific Institute, San Francisco.

Cubillo, F., Moreno, T., Ortega, S., 2008. Microcomponentes y factores explicativos del consumo doméstico de agua en la Comunidad de Madrid. In: Colección de Cuadernos de I+D+I. Canal de Isabel II.

Del Romero, L., 2008. Planificació i govern del territori a líarc mediterrani español: Noves i velles respostes en un context globalitzat. Publicaciones de la Universidad de Valencia, Valencia.

Domene, E., Saurí, D., 2003. Modelos urbanos y consumo de agua. El riego de jardines privados en la Región Metropolitana de Barcelona. Investigaciones Geográficas 32, 5-17.

Domene, E., Saurí, D., 2006. Urbanization and water consumption. Influencing factors in the Metropolitan Region of Barcelona. Urban Stud. 43 (9), 1605-1623.

Domene, E., Saurí, D., Molina, J. et al., 2004. Estudi del consum d'aigua als edificis de la Regió Metropolitana de Barcelona: Situació actual y possibilitats d'estalvi: <http://www.fundacioabertis.org/rcs_est/estudi_complet.pdf>.
Domene, E., Saurí, D., Parés, M., 2005. Urbanization and sustainable resource use: the case of garden watering in the Metropolitan Region of Barcelona. Urban Geogr. 26, 520-535.

Environment Agency, 2008. International Comparisons of Domestic per Capita Consumption. Environment Agency. Government of United Kingdom, Bristol.

European Environment Agency, 2006. The Changing Face of Europe's Coastal Areas. EEA Report no. 6. Copenhagen.

European Environment Agency, 2009. Water resources across Europe. Confronting water scarcity and drought. EEA Report no. 2. Copenhagen.

Fernández, S., Barrado, D.A., 2011. El desarrollo turístico-inmobiliario de la España mediterránea e insular frente a sus referentes internacionales (Florida y la Costa Azul): un análisis comparado. Cuadernos de Turismo 27, 373-402.

Fernández, R., Ordovás, J., Herrera, M.A., 2011. Domestic gardens as water-wis landscapes: a case study in Southwestern Europe. HorTechnology 21 (5), 616-623.

Gaja, F., 2008. El tsunami urbanizador de la costa mediterránea. Scr. Nova 12 (270) $66-75$.

García, X., 2012. Nous procesos d'urbanització i consum d'aigua per a usos domèstics. Una exploració de relacions a l'àmbit gironí. Universitat de Girona (Tesis Doctoral).

García, X., 2014. Jardines privados y consumo de agua en las periferias urbanas de la comarca de la Selva (Girona). Invest. Geográficas 61, 55-69.

Gil, A., Hernández, M., Morote, A.F., Rico, A.M., Saurí, D., March, H., 2015. Causes of the Tendencies of the Water Consumption by Domestic Use and Big Subscribers Between 2007 and 2013, in the city of Alicante and the Metropolitan Area of Barcelona. Institute Interuniversitary of Geography. Universidad de Alicante (in press)

Hernández, M., 2013. Análisis de los procesos de transformación territorial en la provincia de Alicante (1985-2011) y su incidencia en el recurso hídrico a través del estudio bibliográfico. Documents d'Anàlisi Geogràfica 59 (1), 105-136.

Hernández, M., Moltó, E., Rico, A.M., 2008. Las actividades turístico-residenciales en las montañas valencianas. Eria 75, 77-97.

Hernández, M., Rico, A.M., Juárez, C., 2010. Conflicts over water and land use on the coastline of the region of Valencia: agriculture versus the urban city. In: The Suistainable City. Urban Regeneration and Sustainability. WIT Press, Southamton, pp. 405-417.

Hernández, M., Morales, A., Saurí, D., 2014. Ornamental plants and the production of natures in the Spanish real estate boom and burst: the case of Alicante. Urban Geogr. 35 (1), 71-85.

Hof, A., Blázquez-Salom, M., 2013. The linkages between real estate tourism and urban sprawl in Majorca (Balearic Islands, Spain). Land 2, 252-277, http://dx doi.org/10.3390/land2020252.

Hof, A., Schmitt, T., 2011. Urban and tourist land use patterns and water consumption: evidence from Mallorca, Balearic islands. Land Use Policy 28 (4), 792-804.

Hof, A., Wolf, N., 2014. Estimating potential outdoor water consumption in private urban landscapes by coupling high-resolution image analysis, irrigation water needs and evaporation estimation in Spain. Landsc. Urban Plann. 123, 61-72.

Huete, R., 2009. Turistas que llegan para quedarse. Una explicación sociológica sobre la movilidad residencial. Universidad de Alicante, Alicante, Alicante.

Huete, R., Mantecón, A., 2010. Los límites entre el turismo y la migración residencial. Papers 95 (3), 781-801.

Huete, R., Mantecón, A., Mazón, T., 2008. ¿De qué hablamos cuando hablamos de turismo residencial? Cuadernos de Turismo 22, 101-121.

Hurd, B.H., 2006. Water conservation and residential landscape: household preferences, household choices. J. Agric. Resour. Econ. 31, 21-32.

Instituto Nacional de Estadística, 2012. Censos de población y vivienda. 1991. 2001 y 2011. http://www.ine.es/inebmenu/mnu_cifraspob.htm.

Instituto Nacional de Estadística, 2014. Indicadores sobre el suministro de agua po comunidades y ciudades autónomas, principales indicadores y año, http:// www.ine.es/jaxi/tabla.do.

King, R., Warnes, A., Williams, A.M., 2000. Sunset Lives: British Retirement Migration to the Mediterranean. Oxford, Berg.

Larsen, L., Harlan, S.L., 2006. Desert dreamscapes. Residential landscapes preference and behavior. Landsc. Urban Plann. 78, 85-100.

Leichenko, R.M., Solecki, W.D., 2005. Exporting the American dream: the globalization of suburban consumption landscapes. Reg. Stud. 39 (2), 241-253.

Loh, M., Coghlan, P., 2003. Domestic Water Use Study: Perth, Western Australia 1998-2001. Water Corporation, Perth, pp. 1998-2001.

Mantecón Terán, A., 2012. El nexo entre urbanización y turismo. Análisis de la opinión pública. Papers 97 (1), 249-272.

March, H., Saurí, D., 2010. The Suburbanization of water scarcity in the Barcelona metropolitan region: socio-demographic and urban changes influencing domestic water consumption. Prof. Geogr. 1, 32-45.

March, H., Saurí, D., Rico, A.M., 2014. The end of scarcity? Water desalination as the new cornucopia for Mediterranean Spain. J. Hydrol. 519 (2), http://dx.doi.org/ 10.1016/j.jhydrol.2014.04.023, 642-2.652.

Mayer, P.W., Deoreo, W.B., Optiz, E., Kieffer, J., Dziegielewski, B., Davis, W., et al., 1999. Residential End Uses of Water. American Water Works Association Research Foundation, Denver.

Membrado Tena, J.C., 2015. Migración residencial y urbanismo expansivo en el mediterráneo Español. Cuadernos de Turismo 35, 259-285.

Monreal Martínez, J. (dir.), 2001. Un nuevo mercado turístico: jubilados europeos en la región de Murcia. Universidad de Murcia, Murcia.
864

866

868$$
\begin{aligned}
& 88 \\
& 883
\end{aligned}
$$

$$
\begin{aligned}
& 883 \\
& 884 \\
& 885
\end{aligned}
$$$$
\begin{aligned}
& 890 \\
& 89 \\
& 892
\end{aligned}
$$

$$
\begin{aligned}
& 893 \\
& 894
\end{aligned}
$$$$
\begin{aligned}
& 894 \\
& 895 \\
& 896
\end{aligned}
$$

896
897
89

$$
\begin{aligned}
& 898 \\
& 899 \\
& 900
\end{aligned}
$$

800
90$$
\begin{aligned}
& 902 \\
& 903
\end{aligned}
$$

\section{905}

906
907
908
909

\section{911}

$$
\begin{aligned}
& 912 \\
& 913 \\
& 914
\end{aligned}
$$

913
914
915

$$
\begin{aligned}
& 914 \\
& 915 \\
& 916 \\
& 917
\end{aligned}
$$

\section{925}

\section{926
927}

927
928
929

\section{929
930}

930
93
932 
G Model

JLUP 2061 1-11

A.F.M. Seguido, M. Hernández / Land Use Policy xxx (2015) xxx-xxx

11

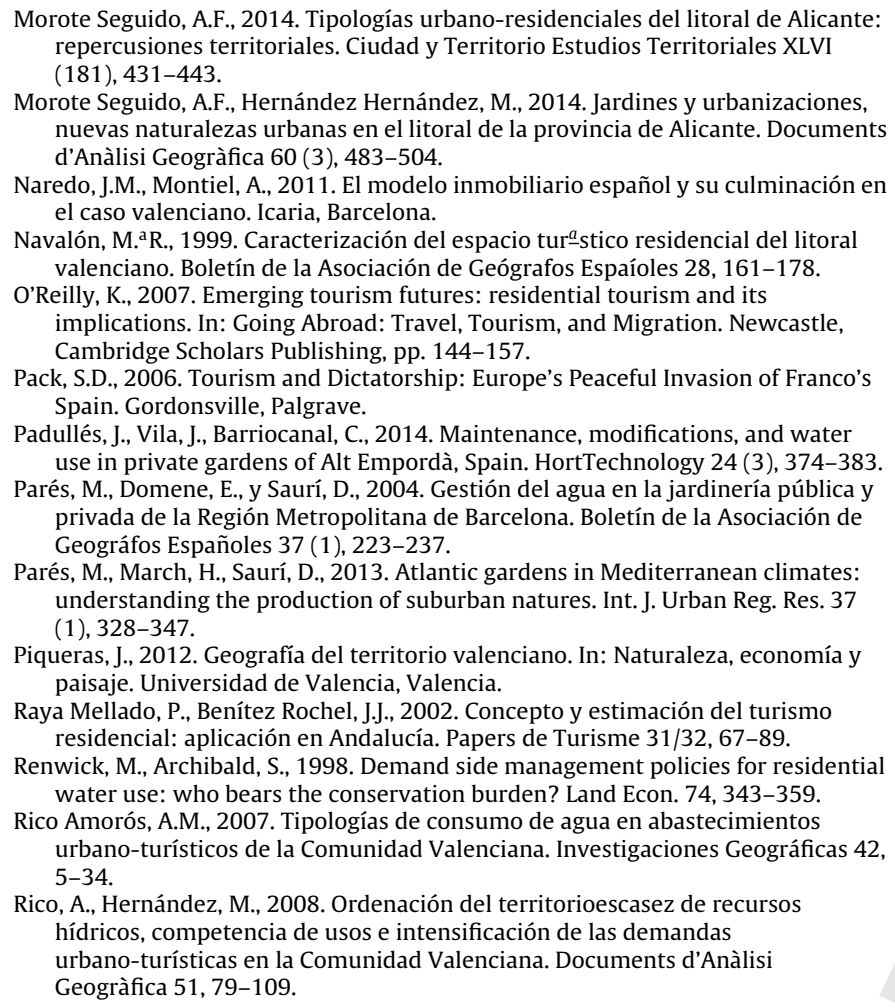

Morote Seguido, A.F., Hernández Hernández, M., 2014. Jardines y urbanizaciones, nuevas naturalezas urbanas en el litoral de la provincia de Alicante. Documents d'Anàlisi Geogràfica 60 (3), 483-504.

Naredo, J.M., Montiel, A., 2011. El modelo inmobiliario español y su culminación en el caso valenciano. Icaria, Barcelona.

Navalón, M. ${ }^{a}$ R., 1999. Caracterización del espacio tur ${ }^{a}$ stico residencial del litoral valenciano. Boletín de la Asociación de Geógrafos Espaíoles 28, 161-178.

O'Reilly, K., 2007. Emerging tourism futures: residential tourism and its implications. In: Going Abroad: Travel, Tourism, and Migration. Newcastle, Cambridge Scholars Publishing, pp. 144-157.

Pack, S.D., 2006. Tourism and Dictatorship: Europe's Peaceful Invasion of Franco's Spain. Gordonsville, Palgrave.

Padullés, J., Vila, J., Barriocanal, C., 2014. Maintenance, modifications, and water use in private gardens of Alt Empordà, Spain. HortTechnology 24 (3), 374-383.

Parés, M., Domene, E., y Saurí, D., 2004. Gestión del agua en la jardinería pública y privada de la Región Metropolitana de Barcelona. Boletín de la Asociación de Geográfos Españoles 37 (1), 223-237.

Parés, M., March, H., Saurí, D., 2013. Atlantic gardens in Mediterranean climates: understanding the production of suburban natures. Int. J. Urban Reg. Res. 37 (1), 328-347.

Piqueras, J., 2012. Geografía del territorio valenciano. In: Naturaleza, economía y paisaje. Universidad de Valencia, Valencia.

Raya Mellado, P., Benítez Rochel, J.J., 2002. Concepto y estimación del turismo residencial: aplicación en Andalucía. Papers de Turisme 31/32, 67-89.

Renwick, M., Archibald, S., 1998. Demand side management policies for residential water use: who bears the conservation burden? Land Econ. 74, 343-359.

Rico Amorós, A.M., 2007. Tipologías de consumo de agua en abastecimientos urbano-turísticos de la Comunidad Valenciana. Investigaciones Geográficas 42, $5-34$.

Rico, A., Hernández, M., 2008. Ordenación del territorioescasez de recursos hídricos, competencia de usos e intensificación de las demandas urbano-turísticas en la Comunidad Valenciana. Documents d'Anàlisi Geogràfica 51, 79-109.

Rico, A., Olcina, J., Saurí, D., 2009. Tourist land use patterns and water demand: evidence from the Western Mediterranean. Land Use Policy 26, 493-501.

Romero, J., Jiménez, F., Villoria, M., 2012. (Un) sustainable territories: causes of the speculative bubble in Spain (1996-2010) and its territorial, environmental, and sociopolitical consequences. Environ. Plann. C: Gov. Policy 30 (3), 467-486.

Salvà, P., 2002. Foreign immigration and tourism development in Spain's Balearic Islands. In: Tourism and Migration: New Relationships Between Production and Consumption. Kluwer Academic Publishers, Londres.

Salvador, R., Bautista, C., Playán, E., 2011. Irrigation perfomance in private urban landscapes: a study case in Zaragoza (Spain). Landsc. Urban Plann. 100, 302-311.

Salvati, L., Sabbi, A., 2011. Exploring long term land cover changes in an urban region of Southern Europe. Int. J. Sustain. Dev. World Ecol. 18 (4), 273-282.

Saurí, D., 2003. Lights and shadows or urban water demand management: the case of the Metropolitan Region of Barcelona. Eur. Plann. Stud. 11, 229-243.

Schleich, J., Hillenbrand, T., 2007. Determinants of residential water demand in Germany. In: Working Paper Sustainability and Innovation 3/2007. Institute Systems and Innovation Research.

Swyngedouw, E., 1999. Modernity and hibridity: nature, regeneracionismo, and the production of the Spanish waterscape, 1890-1930. Ann. Assoc. Am. Geogr. 89 (3), 443-465.

Swyngedouw, E., 2004. Social Power and the Urbanization of Water. Oxford University Press, Oxford.

Torrero, A., 2001. El final de la burbuja especulativa y la crisis económica de Japón. Ekonomiaz 48, 92-127.

Torres Alfosea, F.J., 1997. Ordenación del litoral en la Costa Blanca. Universidad de Alicante, Alicante.

Troy, P., Holoway, D., 2004. The use of residential water consumption as an urban planning tool: a pilot study in Adelaide. J. Environ. Plann. Manag. 47, 97-114.

Vera, J.F., 1987. Turismo y urbanización en el litoral alicantino. Instituto de Estudios Juan Gil-Albert, Alicante.

Vera Rebollo, J.F., 2005. El auge de la función residencial en destinos turísticos del litoral mediterráneo: entre el crecimiento y la renovación. Papers de Turisme 37/38, 95-114.

Vidal, M., Domene, E., Saurí, D., 2011. Changing geographies of water-related consumption: residential swimming pools in suburban Barcelona. Area 43 (1), 67-75.
985
986
987
988
983
989
990
991
992
993
994
995
996
997
998
999
99
100
100
100
100
103
100
100
1006
100
1007
1008
1009
1010
101
101
1012
1013
101
1015
1016
1017
1018
1019
1020
102

Please cite this article in press as: Seguido, A.F.M., Hernández, M., Urban sprawl and its effects on water demand: A case study of Alicante, Spain. Land Use Policy (2015), http://dx.doi.org/10.1016/j.landusepol.2015.06.032 